\title{
HERRING GULL HARASSES AMERICAN AVOCET
}

WILLIAM H. KOONZ, Department of Natural Resources, Box 24, 200 Saulteaux Cr., Winnipeg, MB, R3J 3W3

On 4 June 1998, Dr. Robert Jones and I were evaluating Piping Plover (Charadrius melodus) nest initiation on West Shoal Lake, some 40 kilometres northwest of Winnipeg, Manitoba. Lake water levels were high, at least $1 \mathrm{~m}$ above those of the 1980's. I waded out to three islands that had been part of the main plover nesting peninsula throughout the 1980's. No plovers were seen there but two islands contained Ring-billed Gull (Larus delawarensis) colonies totalling just over 600 nests. During my return to shore, I witnessed the aerial harassment of an adult American Avocet (Recurvirostra americana) by a Herring Gull (Larus argentatus).

The event took place along the lakeshore and at times some distance inland over lightly forested areas. The gull appeared to attempt to force the avocet down either into the water or onto the ground. It continually approached the avocet from above and behind. The avocet eluded the gull by making sharp turns or by flying through breaks in woody shoreline vegetation. When the gull misjudged the avocet's manoeuvre and lost distance, it flew some distance into the air and quickly overtook the apparently tiring, slower, avocet.

I do not know how long the harassment continued nor its outcome but it was ongoing for at least 15 minutes. The two birds manoeuvred along the shoreline to the south then northwest until I could no longer see them with my binoculars.
Herring Gulls are opportunistic and take many types of prey by a number of methods. ${ }^{2}$ Pellets from some incubating great lakes Herring Gull colonies contained as high as $7 \%$ adult birds including Northern Flickers, American Robins, Red-winged Blackbirds, Blue Jays and Downy Woodpeckers. ${ }^{1}$ This report did not provide information on how those food items were obtained, e.g. captured live or scavenged. Nesting Herring Gulls on Great Island, Newfoundland typically specialized on human refuse, blue mussels or adult Leach's StormPetrels. These were the only three food items making up over $1 \%$ of the materials teased from pellets found on the nesting colony. ${ }^{2}$ How Leach's Storm-petrels were obtained was not mentioned. No mention of aerial harassment was made in The Birds of North America account of the Herring Gull. ${ }^{3}$ Dr. Brian Knudsen (pers. Comm.) indicated that he had received second-hand information that Herring Gulls were able to capture and kill adult shorebirds which had been netted for banding. These birds were attacked from atop the release shed in which banding, streamer attachment and handling took place (banded shorebirds were released out a port which was some distance from the ground; Herring Gulls perched on top of the building and dove to capture shorebirds shortly after release). I have seen Herring Gulls attack the unprotected eggs and young of colonial nesting waterbirds, pluck young ducks and grebes from the water and take live rodents attempting to escape fires, but this was my first 
